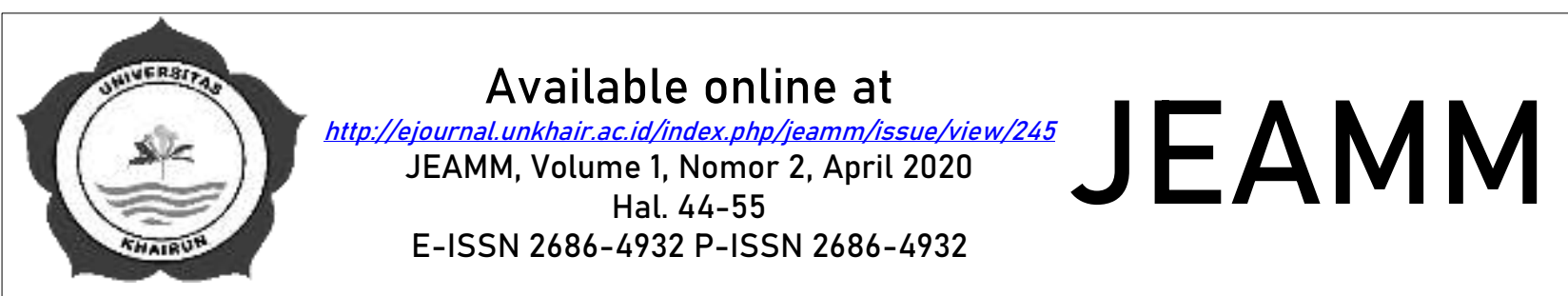

\title{
PENGETAHUAN, MODAL MINIMAL, MOTIVASI INVESTASI DAN MINAT MAHASISWA UNTUK BERINVESTASI DI PASAR MODAL
}

\author{
${ }^{1}$ Suriana AR. Mahdi, ${ }^{2}$ Gregorius Jeandry, ${ }^{3}$ Fitria Abd. Wahid \\ 1,2,3Fakultas Ekonomi dan Bisnis Universitas Khairun \\ Email: ${ }^{1}$ suriana.armahdi@gmail.com, ${ }^{2}$ gjeandry@gmail.com \\ 3fitri.abdulwahid@gmail.com
}

Dikirim, 10 Maret 2020

Revisi, 15 Maret 2020

Diterima, 27 Maret 2020

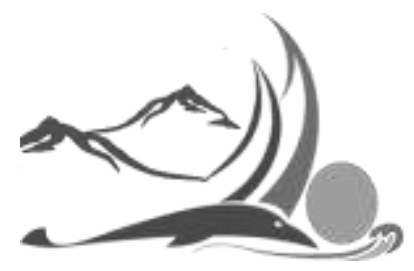

Jurnal Ekonomi, Akuntansi dan Manajemen

Multiparadigma

Volume 1, Nomor 2,

April 2020

\begin{abstract}
ABSTRAK
Penelitian ini bertujuan untuk mengetahui Apakah pengetahuan, modal minimal dan motivasi investasi berpengaruh terhadap minat berinvestasi. Populasi dalam penelitian ini adalah seluruh mahasiswa yang terdaftar pada Galeri Investasi Bursa Efek Indonesia (GI-BEI) di tiga perguruan tinggi di Kota Ternate yakni Universitas khairun Ternate, Institut Agama Islam Negeri Ternate, Universitas Muhammadiyah Maluku Utara. Metode penentuan sampel yang digunakan adalah purposive sampling dan sampel dalam penelitian ini sebanyak 101 mahasiswa. Analisis data dalam penelitian ini mengunakan analisis regresi berganda dengan bantuan SPSS versi 22. Hasil penelitian ini menunjukan bahwa pengetahuan dan motivasi investasi berpengaruh terhadap minat mahasiswa untuk berinvestasi di pasar modal sedangkan modal minimal tidak berpengaruh tehadap minat mahasiswa untuk berinvestasi di pasar modal.
\end{abstract}

Kata Kunci: Modal Minimal, Motivasi Investasi, Minat Berinvestasi

\section{ABSTRACT}

This research study aim to determine influence of knowledge, capital Minimal and investment motivation influence investment interest. The population in this study were all students registered at the Indonesia Stock Exchange Investment Gallery (GI-BEI) in three universities in Ternate City, namely the Universitas Khairun Ternate, State Islamic Institute Ternate, Muhammadiyah University North Maluku. The sampling method used was purposive sampling and the sample in this study was 101 students. Analysis of the data in this study uses multiple regression analysis with the help of SPSS version 22. The results of this study indicate that knowledge and motivation Investment affect student interest in investing in the market Capital while minimal capital has no effect on student interest in investing in the capital market

Keywords: Knowledge, Minimal Capital, Investment Motivation, Interests Investing 


\section{PENDAHULUAN}

Perkembangan ekonomi dan teknologi komunikasi yang sangat pesat memberikan begitu banyak kemudahan dalam dunia bisnis. Hal ini terlihat dengan banyaknya perusahaan-perusahaan yang berdiri dan berkembang dengan memanfaatkan fasilitas teknologi. Selain itu, perkembangan bisnis ini juga berdampak pada meningkatnya daya saing antar perusahaan sehingga setiap perusahaan dituntut untuk selalu mengembangkan strategi perusahaan. Dalam pengembangan strategi itulah, maka perusahaan membutuhkan dana tambahan untuk menunjang produktivitas, olehnya strategi yang diambil perusahaan adalah dengan bergabung di pasar modal (Pajar, 2017). Raditya dan Suardika (2014) menjelaskan bahwa pasar modal yakni suatu pasar (tempat, berupa gedung) yang disiapkan guna memperdagangkan saham-saham, obligasi-obligasi dan jenis surat berharga lainnya dengan memakai jasa para perantara efek. Dapat dipahami bahwa pasar modal merupakan suatu instrument dalam mempertemukan antar kedua belah pihak yakni pemilik dana (investor) maupun calon investor dan pihak yang membutuhkan dana. Dalam pandangan investor maupun calon investor mempersepsikan dua paradigma yakni keinginan dan kebutuhan.

Galeri Investasi Bursa Efek Indonesia (GI-BEI) merupakan sarana untuk memperkenalkan pasar modal sejak dini kepada dunia akademisi dengan harapan mahasiswa tidak hanya mengenal pasar modal dari sisi teoretis saja, akan tetapi juga praktiknya. Galeri Investasi yang berada di perguruan tinggi di Lingkungan Maluku Utara, seperti; Universitas Khairun, IAIN Ternate, dan Universitas Muhammadiyah Maluku Utara, merupakan pojok bursa yang memberikan kemudahan akses kepada masyarakat untuk berinvestasi di pasar modal, dan juga berfungsi sebagai media edukasi pasar modal. Operasional Galeri Investasi dijalankan oleh Dana reksa Sekuritas dan Kelompok Studi Pasar Modal (KSPM) yang mana merupakan suatu kelompok mahasiswa yang mengkaji tentang pasar modal.

Berdasarkan hasil wawancara sementara yang dilakukan peneliti dengan pengelola Galeri Investasi, mengungkapkan bahwa minat berinvestasi mahasiswa pada ketiga perguruan tinggi tersebut terbilang cukup rendah. Hal ini dibuktikan dengan jumlah investor yang terdaftar pada data pembukuan investasi di Galeri Investasi Bursa Efek Indonesia periode 2018-2019. Lebih jelasnya dapat dilihat pada Tabel 1 berikut ini

Tabel 1 Jumlah Nasabah Galeri Investasi periode 2018-2019

\begin{tabular}{cccc}
\hline Tahun & $\begin{array}{c}\text { Universitas } \\
\text { Khairun }\end{array}$ & $\begin{array}{c}\text { Universitas Muhammadiyah } \\
\text { Maluku Utara }\end{array}$ & $\begin{array}{c}\text { IAIN } \\
\text { Ternate }\end{array}$ \\
\hline 2018 & 34 & 60 & 25 \\
\hline 2019 & 60 & 32 & 8 \\
\hline
\end{tabular}

Sumber: Galeri Investasi Universitas Khairun Ternate, IAIN Ternate, dan Universitas Muhammadiyah Maluku Utara, 2019

Berdasarkan tabel di atas dapat dipahami bahwa jumlah investor pada galeri investasi tidak sebanding dengan jumlah mahasiswa yang aktif pada perguruan tinggi tersebut. hal ini yang membuat peneliti ingin mengetahui lebih lanjut bagaimana tanggapan mahasiswa dalam berinvestasi di pasar modal. Jika dilihat dari latar belakang pendidikannya seharusnya mahasiswa tersebut sudah memiliki pengetahuan yang cukup tentang pasar modal. Adapun beberapa faktor yang mempengaruhi minat berinvestasi di pasar modal yakni, pengetahuan, modal minimal dan motivasi berinvestasi.

Pengetahuan investasi merupakan pemahaman yang harus dimiliki seseorang dalam berinvestasi dimulai dari pengetahuan dasar penilaian investasi, tingkat risikonya dan 
tingkat pengembalian (return) investasi Kusmawati (2011). Bahwa untuk melakukan investasi di pasar modal diperlukan pengetahuan yang cukup, pengalaman serta naluri bisnis untuk menganalisis efek-efek mana yang akan dibeli.

Pengetahuan yang memadai sangat diperlukan untuk menghindari terjadinya kerugian saat berinvestasi hal tersebut yang membentuk perilaku investor maupun calon investor untuk berinvestasi di pasar modal. Dalam theory of planned behavior menjelaskan bahwa sikap dan perilaku seseorang dalam melakukan tindakan tak terlepas dari perilaku investor dalam membuat keputusan berinvestasi. Penelitiannya Sari (2018) dan Latifah (2019) hasil penelitiannya menunjukan bahwa pengetahuan investasi berpengaruh terhadap minat berinvestasi di pasar modal syariah, namun hal ini tidak sejalan dengan penelitiannya Malik (2017) yang dimana hasil penelitiannya menunjukan bahwa pengetahuan investasi tidak berpengaruh terhadap minat investasi di pasar modal syariah. Di sisi lain minat berinvestasi tidak hanya dipengaruhi oleh variabel pengetahuan investasi namun dapat pula dipengaruhi oleh variabel modal minimal.

Modal minimal merupakan salah satu dari faktor yang harus dipertimbangkan seseorang sebelum mengambil keputusan untuk berinvestasi (Pajar, 2017). Modal minimal investasi dijadikan pertimbangan karena di dalamnya terdapat perhitungan estimasi dana untuk investasi, semakin minimum dana yang dibutuhkan akan semakin tinggi pula minat seseorang untuk berinvestasi. Menurut Raditya dan Suardika (2014) menyatakan bahwa modal minimal investasi merupakan sebuah diskon besar-besaran yang terjadi di department store, diskon ini memicu seseorang untuk berbelanja. Dalam penelitiannya Dewi dan Asana (2017) dan Latifah (2019) hasilnya menunjukan bahwa modal minimal berpengaruh terhadap minat investasi di pasar modal syariah. Namun hal ini tidak sejalan dengan penelitiannya Winantiyo (2017) dan Sundari (2019) hasilnya menunjukan bahwa modal minimal tidak berpengaruh terhadap minat investasi di pasar modal syariah. Ada pula variabel lain yang dapat mempengaruhi minat dalam berinvestasi di pasar modal yakni variabel motivasi

Motivasi sangat berperan penting dalam menumbuhkan minat seseorang dalam berinvestasi karena motivasi adalah semangat yang mendorong seseorang untuk melakukan sesuatu. Latifah (2019) menjelaskan bahwa motivasi merupakan keadaan dalam pribadi seseorang yang mendorong keinginan individu untuk melakukan kegiatan-kegiatan tertentu. Pengukuran dilakukan dengan cara melihat tindakan yang diambil oleh seseorang, apakah memiliki dorongan yang kuat dalam mengambil keputusan setelah mendapatkan berbagai informasi yang mendukung suatu tindakan tersebut akan mempengaruhi minat dalam berinvestasi. Dalam penelitian Latifah (2019), Pajar (2017), Nisa dan Zulaika (2017) hasil penelitian menunjukan bahwa motivasi berpengaruh terhadap minat berinvestasi. Dalam theory of planed behavior menjelaskan bahwa sikap dan perilaku seseorang dalam melakukan tindakan tidak terlepas dari perilaku seseorang dalam berinvestasi. Namun dalam kenyataannya, dilihat dari sikap dan perilaku hanya segelintir mahasiswa yang saat ini termotivasi untuk berinvestasi di pasar modal.

Mahasiswa Fakultas Ekonomi Universitas Khairun Ternate, Fakultas Syariah Ekonomi Islam dan Mahasiswa Fakultas Ekonomi Universitas Muhammadiyah Maluku Utara memberikan edukasi tentang Investasi dalam pasar modal. Meskipun demikian, dalam praktik langsung untuk terlibat dalam investasi pasar modal rata-rata mahasiswa terbilang cukup rendah serta kaku untuk melakukan transaksi investasi. Meskipun saat ini terdapat Galeri Investasi pasar modal yang itu menjadi media dalam belajar praktik cara berinvestasi untuk membuat mahasiswa memiliki gambaran secara keseluruhan tentang bagaimana cara untuk berinvestasi. Maka dari itu, dapat dikatakan bahwa minat mahasiswa 
masuk ke dunia investasi masih tergolong rendah, olehnya itu minat investasi sangat menarik untuk diteliti kembali.

Dalam penelitian ini, peneliti mereplikasi penelitiannya Latifah (2019). dengan judul "pengaruh pengetahuan, modal minimal dan motivasi investasi terhadap minat mahasiswa untuk berinvestasi di pasar modal syariah (studi pada galeri investasi syariah UMP). Namun, ada beberapa hal yang membuat penelitian ini berbeda dengan sebelumnya yakni waktu penelitian, tempat penelitian, objek penelitian serta penelitian ini dimaksudkan untuk menguji kembali konsistensi hasil penelitian terdahulu dan juga penelitian sebelumnya yang merekomendasikan untuk menggunakan sampel yang lebih banyak sehingga hasil yang dihasilkan akan lebih meyakinkan.

Berdasarkan deskripsi di atas, maka dalam penelitian ini, peneliti memfokuskan penelitiannya pada, apakah pengetahuan, modal minimal dan motivasi investasi berpengaruh terhadap minat mahasiswa berinvestasi di pasar modal. Penelitian ini bertujuan untuk mengetahui apakah pengetahuan, modal minimal dan motivasi investasi berpengaruh terhadap minat mahasiswa berinvestasi di pasar modal.

Pelatihan mengenai pasar modal dan seminar-seminar investasi mengenai pasar modal merupakan bentuk pembelajaran bagi calon investor yang terlibat di dalamnya untuk menambah wawasan pengetahuan tentang investasi yang kemudian akan menumbuhkan minat bagi individu tersebut dalam mengambil tindakan untuk berinvestasi di pasar modal. Pengetahuan dasar merupakan salah satu faktor yang memudahkan seseorang untuk mengambil keputusan berinvestasi, karena pengetahuan merupakan dasar pembentukan sebuah kekuatan bagi seseorang untuk mampu melakukan sesuatu yang diinginkannya (Efferin, 2006). Sejalan dengan Theory of Planned Behavior, aktivitas pembelajaran akan menyebabkan suatu perubahan tingkah laku sebagai hasil dari pengalaman individu dalam interaksi dalam lingkungannya yang menyangkut kognitif, afektif dan psikomotorik (Ajzen, 1991). Sehingga untuk menumbuhkan minat seseorang dalam mengambil tindakan untuk berinvestasi di perlukan pengetahuan investasi yang memadai bagi calon investor tersebut.

Penelitian terdahulu Sari (2018) dan Latifah (2019) menyatakan bahwa pengetahuan berpengaruh terhadap minat berinvestasi di pasar modal, berdasarkan teori dan penelitian terdahulu maka dapat dirumuskan hipotesis sebagai berikut:

\section{H1: Pengetahuan investasi berpengaruh terhadap minat berinvestasi di pasar modal.}

Modal minimal investasi merupakan salah satu faktor yang menjadi pertimbangan yang memperkuat minat seseorang dalam mengambil tindakan untuk berinvestasi di pasar modal. Modal minimal investasi dijadikan pertimbangan karena di dalamnya terdapat perhitungan estimasi dana untuk investasi, semakin minimum dana yang dibutuhkan akan semakin tinggi pula minat seseorang untuk berinvestasi, Pajar (2017). Sebelum mengambil tindakan untuk berinvestasi mahasiswa khususnya, akan berfikir mengenai modal awal yang harus dikeluarkan untuk berinvestasi di pasar modal mengingat sebagian besar mahasiswa belum memiliki penghasilan tetap.

Theory of Planned Behavior dapat diaplikasikan dalam sikap dan perilaku calon investor. Dikeluarkannya peraturan perubahan satuan perdagangan fraksi harga yang tertera pada surat keputusan Nomor: Kep-00071/BEI/11-2013, surat keputusan tersebut menurunkan modal minimal investasi sebesar Rp100.000 (Adiguna, 2018). Dengan dikeluarkannya keputusan penurunan modal minimal investasi hal tersebut dapat memperkuat minat seseorang dalam mengambil tindakan untuk berinvestasi di pasar modal. Dewi dan Asanah (2017) dan Latifah (2019) dalam hasil penelitiannya menunjukkan bahwa modal minimal berpengaruh terhadap minat berinvestasi di pasar modal. 
Berdasarkan teori dan penelitian terdahulu maka dapat dirumuskan hipotesis sebagai berikut:

H2: Modal minimal berpengaruh terhadap minat berinvestasi di pasar modal.

Umumnya tindakan yang dilakukan seseorang untuk memanfaatkan kelebihan dananya ialah dengan menabung atau mendepositokan. Tindakan ini biasanya dilakukan oleh orang-orang yang masuk dalam kategori takut risiko (risk averse). Berbeda halnya dengan orang dalam kategori penantang risiko (risk taker), mereka cenderung untuk menginvestasikan dananya pada bentuk-bentuk investasi. Keuntungan yang lebih besar yang akan diperoleh kemudian hari merupakan faktor pendorong seseorang dalam mengambil keputusan berinvestasi meskipun risiko yang dihadapi juga besar seperti investasi pada saham. Jadi keinginan ataupun motivasi berinvestasi timbul karena kebutuhan substansial seseorang sudah terpenuhi, sehingga kebutuhan yang ingin dipenuhi selanjutnya adalah kebutuhan sosial, kebutuhan penghargaan, dan aktualisasi diri (Kusmawati, 2011). Berdasarkan Theory of Planned Behavior (TPB) menjelaskan bahwa Tindakan yang diambil oleh seseorang didasari untuk memenuhi kebutuhan dan hasratnya. Berbagai kebutuhan baik itu kebutuhan sosial, kebutuhan penghargaan ataupun kebutuhan aktualisasi diri dapat menjadi pemicu seseorang untuk melakukan tindakan atau keputusan di luar kehidupan sehari-hari. Salah satu contohnya adalah seseorang mengambil keputusan untuk melakukan investasi. Kebutuhan berinvestasi dilakukan oleh seseorang jika kebutuhan substansialnya sudah terpenuhi, seperti kebutuhan psikologis dan kebutuhan keamanan. Penelitian Pajar (2017), Efferin (2006) dan Latifah (2019) menyatakan bahwa Motivasi Investasi berpengaruh terhadap minat berinvestasi di pasar modal. Berdasarkan teori dan penelitian terdahulu maka dapat dirumuskan hipotesis sebagai berikut.

H3: Motivasi Investasi Berpengaruh Terhadap Minat Berinvestasi Di Pasar Modal

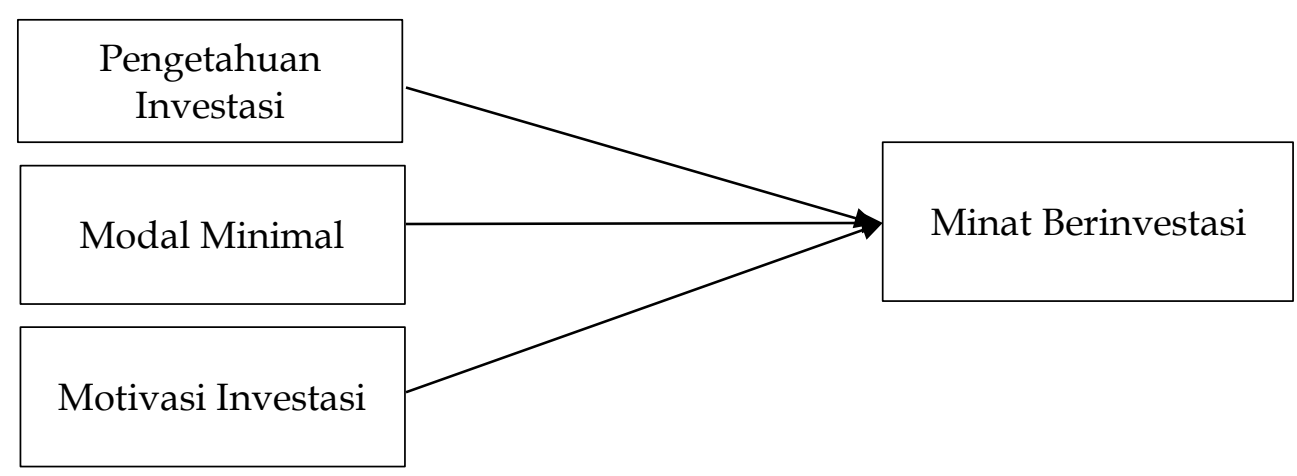

Gambar 1 Kerangka Pikir

\section{METODE PENELITIAN}

Populasi dalam penelitian ini adalah seluruh mahasiswa yang terdaftar pada Galeri Investasi Bursa Efek Indonesia (GI-BEI) Universitas Khairun Ternate, Institut Agama Islam Negeri (IAIN), dan Universitas Muhammadiyah Maluku Utara sebanyak 219. Sedangkan metode penentuan sampel yang digunakan dalam penelitian ini adalah metode purposive sampling, dimana populasi yang akan dijadikan sampel penelitian adalah populasi yang memenuhi kriteria sampel tertentu. Kriteria dari sampel tersebut adalah mahasiswa aktif yang tercatat sebagai investor pada Galeri Investasi (GI-BEI). Universitas Khairun Ternate, Institut Agama Islam Negeri (IAIN), dan Universitas Muhammadiyah Maluku Utara yang terdaftar pada periode 2018-2019 serta mahasiswa yang telah mengikuti pelatihan pasar modal 
Jenis data yang digunakan dalam penelitian ini merupakan data kuantitatif, sedangkan sumber data yang digunakan adalah data sekunder. Data yang digunakan dalam variabel dependen minat berinvestasi di pasar modal. Sementara data yang digunakan dalam variabel independen pengetahuan, modal minimal dan motivasi investasi. Dalam penelitian ini menggunakan teknik pengumpulan data field research (penelitian lapangan). Teknik pengumpulan data pada penelitian ini menggunakan metode survei dalam bentuk kuesioner yang diberikan secara personal.

Berdasarkan hipotesis dalam penelitian ini maka model analisis yang digunakan adalah analisis regresi linear berganda, uji t dan uji F dengan mengacu dari Ghozali, (2018). Analisis ini meliputi pengelolaan data, pengorganisasian data dan penemuan hasil pengujian data yang dilakukan dalam penelitian ini adalah dengan menggunakan model regresi linear berganda. Adapun pengujian yang dilakukan adalah sebagai berikut:

$$
\mathrm{Y}=\mathrm{\alpha}+\beta 1 \mathrm{X} 1+\beta 2 \mathrm{X} 2+\beta 3 \mathrm{X3}
$$

Instrumen pengukuran variabel ini menggunakan pertanyaan yang dikembangkan oleh Pajar (2017) terdiri dari 11 (sebelas) item pertanyaan. Instrumen pengukuran variabel ini menggunakan pertanyaan yang dikembangkan oleh Susilowati (2017) terdiri dari 3 (tiga) item pertanyaan. Instrumen pengukuran variabel ini menggunakan pertanyaan yang dikembangkan oleh Pajar (2017) terdiri dari 9 (sembilan) item pertanyaan. Instrumen pengukuran variabel ini menggunakan pertanyaan yang dikembangkan oleh Pajar (2017) terdiri dari 7 (tujuh) item pertanyaan. Keseluruhan instrumen dalam penelitian ini menggunakan skala likert 5 poin yang terdiri dari (1) sangat tidak setuju sampai (5) Sangat setuju.

\section{HASIL DAN PEMBAHASAN}

Berdasarkan analisis statistik deskriptif pada tabel 2 dapat dianalisa bahwa variabel pengetahuan dapat diukur dengan menggunakan instrument yang terdiri dari 11 pertanyaan dan dinilai dengan 5 poin skala likert yaitu 1 (sangat tidak setuju) dan 5 (sangat setuju) untuk semua variabel dalam penelitian ini, sehingga diperoleh jawaban minimum dari responden untuk variabel pengetahuan pada kisaran 34,00 dan jawaban maksimum berada pada kisaran 54,00 dengan rata-rata (mean) 43,06 dan standar deviasi 4.109 dari total 101 responden. Untuk variabel modal minimal diperoleh jawaban minimum dari responden untuk variabel modal minimal pada kisaran 9,00 dan jawaban maximum berada pada kisaran 15,00 dengan rata-rata (mean) 12.40 dan standar deviasi 1.401 dari total 101 responden. Untuk variabel motivasi investasi diperoleh jawaban minimum dari responden untuk variabel modal minimal pada kisaran 25,00 dan jawaban maximum berada pada kisaran 43,00 dengan rata-rata (mean) 34.15 dan standar deviasi 3.602 dari total 101 responden. Untuk variabel minat mahasiswa berinvestasi diperoleh jawaban minimum dari responden untuk variabel modal minimal pada kisaran 21,00 dan jawaban maximum berada pada kisaran 35,00 dengan rata-rata (mean) 28.04 dan standar deviasi 3.011 dari total 101 responden.

Tabel 2 Statistik Deskriptif

\begin{tabular}{lccccc}
\hline \multicolumn{1}{c}{ Variabel } & $\mathrm{N}$ & Minimum & Maksimum & Mean & SD \\
\hline Pengetahuan & 101 & 34.00 & 54.00 & 43.06 & 4.109 \\
\hline Modal Minimal & 101 & 9.00 & 15.00 & 12.40 & 1.401 \\
\hline Motivasi Investasi & 101 & 25.00 & 43.00 & 34.15 & 3.602 \\
\hline Minat Mahasiswa Berinvestasi & 101 & 21.00 & 35.00 & 28.04 & 3.011 \\
\hline \multicolumn{2}{c}{ Sumber: Data Primer Diolah, Peneliti (2019) } & & &
\end{tabular}


Uji validitas digunakan untuk menguji variabel independen yakni pengetahuan, modal minimal dan motivasi investasi sedangkan untuk variabel dependen adalah minat mahasiswa berinvestasi level signifikansi 0,05 nilai kritisnya (Ghozali, 2013). Berdasarkan hasil uji validitas pada tabel 3 menunjukkan bahwa indikator pengetahuan, modal minimal, motivasi investasi dan minat mahasiswa berinvestasi yang digunakan mempunyai nilai signifikansi 0,000 tidak melebihi nilai 0,05. Hal ini berarti item dalam pernyataan yang digunakan dalam penelitian ini layak atau valid untuk digunakan sebagai pengumpul data.

Tabel 3 Hasil Uji Validitas (X1)

\begin{tabular}{|c|c|c|c|c|}
\hline Variabel & Item & $\begin{array}{c}\text { Person } \\
\text { Correlation }\end{array}$ & Sig & Keterangan \\
\hline \multirow[t]{11}{*}{ Pengetahuan } & X1.1 & 0,436 & 0,000 & Valid \\
\hline & X1.2 & 0,384 & 0,000 & Valid \\
\hline & X1.3 & 0,572 & 0,000 & Valid \\
\hline & X1.4 & 0,567 & 0,000 & Valid \\
\hline & X1.5 & 0,711 & 0,000 & Valid \\
\hline & X1.6 & 0,658 & 0,000 & Valid \\
\hline & X1.7 & 0,337 & 0,001 & Valid \\
\hline & X1.8 & 0,600 & 0,000 & Valid \\
\hline & X1.9 & 0,696 & 0,000 & Valid \\
\hline & X1.10 & 0,563 & 0,000 & Valid \\
\hline & X1.11 & 0,474 & 0,000 & Valid \\
\hline \multirow[t]{3}{*}{ Modal Minimal } & $\mathrm{X} 2.1$ & 0,724 & 0,000 & Valid \\
\hline & $X 2.2$ & 0,799 & 0,000 & Valid \\
\hline & $X 2.3$ & 0,738 & 0,000 & Valid \\
\hline \multirow[t]{18}{*}{ Motivasi Investasi } & X3.1 & 0,613 & 0,000 & Valid \\
\hline & X3.2 & 0,629 & 0,000 & Valid \\
\hline & X3.3 & 0,599 & 0,000 & Valid \\
\hline & X3.4 & 0,703 & 0,000 & Valid \\
\hline & X3.5 & 0,577 & 0,000 & Valid \\
\hline & X3.6 & 0,618 & 0,000 & Valid \\
\hline & X3.7 & 0,652 & 0,000 & Valid \\
\hline & X3.8 & 0,618 & 0,000 & Valid \\
\hline & X3.9 & 0,556 & 0,000 & Valid \\
\hline & X3.1 & 0,613 & 0,000 & Valid \\
\hline & X3.2 & 0,629 & 0,000 & Valid \\
\hline & X3.3 & 0,599 & 0,000 & Valid \\
\hline & X3.4 & 0,703 & 0,000 & Valid \\
\hline & X3.5 & 0,577 & 0,000 & Valid \\
\hline & X3.6 & 0,618 & 0,000 & Valid \\
\hline & X3.7 & 0,652 & 0,000 & Valid \\
\hline & X3.8 & 0,618 & 0,000 & Valid \\
\hline & X3.9 & 0,556 & 0,000 & Valid \\
\hline \multirow[t]{5}{*}{ Minat Mahasiswa Berinvestasi } & Y1 & 0,576 & 0,000 & Valid \\
\hline & $\mathrm{Y} 2$ & 0,597 & 0,000 & Valid \\
\hline & Y3 & 0,570 & 0,000 & Valid \\
\hline & Y4 & 0,680 & 0,000 & Valid \\
\hline & Y5 & 0,764 & 0,000 & Valid \\
\hline
\end{tabular}




\begin{tabular}{ccccc}
\hline Variabel & Item & $\begin{array}{c}\text { Person } \\
\text { Correlation }\end{array}$ & Sig & Keterangan \\
\hline & $\mathrm{Y} 6$ & 0,580 & 0,000 & Valid \\
\cline { 2 - 5 } & $\mathrm{Y} 7$ & 0,606 & 0,000 & Valid \\
\hline
\end{tabular}

Sumber: Data Primer Diolah, Peneliti (2019)

Pengukuran reliabilitas dalam penelitian ini adalah dengan uji statistik Cronbach's Alpha (a). Suatu konstruk atau variabel dikatakan reliabilitas jika memberikan nilai Cronbach Alpha > 0,6. Ghozali (2013). Hasil uji reliabilitas pada tabel 4 menunjukkan bahwa nilai Cronbach's Alpha $(\alpha)$ untuk variabel pengetahuan, modal minimal, modal investasi dan minat mahasiswa berwirausaha berada di atas angka 0,70 untuk masing-masing variabel dalam penelitian ini. Data tersebut juga menunjukkan bahwa setiap variabel yang digunakan dalam penelitian ini dinyatakan handal atau reliabel. Artinya setiap item mampu memperoleh data yang konsisten yang berarti bila pertanyaan itu diajukan kembali akan diperoleh jawaban yang relatif sama dengan jawaban sebelumnya.

Tabel 4 Hasil Uji Reliabilitas

\begin{tabular}{lcc}
\hline \multicolumn{1}{c}{ Variabel } & $\begin{array}{c}\text { Cronbach's } \\
\text { Alpha (a) }\end{array}$ & Keterangan \\
\hline Pengetahuan & 0,760 & Reliable \\
\hline Modal Minimal & 0,616 & Reliable \\
\hline Motivasi Investasi & 0,793 & Reliable \\
\hline Minat Mahasiswa Berinvestasi & 0,733 & Reliable \\
\hline Sumber: Data Primer Diolah, Peneliti (2019) &
\end{tabular}

Berdasarkan tabel 5 menunjukkan bahwa persamaan regresi berganda diketahui nilai Adjusted R2 adalah 0,300, hal tersebut berarti bahwa 30\% variabel minat mahasiswa untuk berinvestasi dapat dijelaskan oleh pengetahuan, modal minimal dan motivasi, selisihnya yaitu sebesar $70 \%$ dijelaskan oleh variabel-variabel yang lain di luar persamaan. Nilai Fhitung sebesar 15,287 dengan Sig. F sebesar 0,000. Angka Sig. F dari persamaan tersebut lebih kecil dari nilai 0,05 atau $<0,05$, dengan demikian dapat disimpulkan bahwa model yang digunakan untuk menguji pengetahuan, modal minimal dan motivasi bersama-sama berpengaruh terhadap minat mahasiswa berinvestasi di pasar modal.

Berdasarkan hasil perhitungan tabel 5 pada persamaan regresi berganda dapat diketahui bahwa pertama, hasil uji hipotesis pertama menunjukan nilai thitung sebesar 2,629 dengan signifikansi sebesar 0,010 yang lebih kecil dari tingkat signifikansi $(\alpha)=5 \%$ atau 0,05. Hasil ini menunjukkan bahwa variable pengetahuan berpengaruh positif terhadap minat mahasiswa untuk berinvestasi di pasar modal. Dengan demikian $\mathrm{H}_{1}$ diterima. Kedua, Hasil uji hipotesis kedua menunjukan nilai $t$ hitung sebesar -0,778 dengan signifikansi sebesar 0,439 yang lebih besar dari tingkat signifikansi $(\alpha)=5 \%$ atau 0,05 . Hasil ini menunjukkan variable modal minimal tidak berpengaruh terhadap Minat Mahasiswa Untuk Berinvestasi di Pasar Modal. Dengan demikian H2 ditolak. Ketiga, Hasil uji hipotesis ketiga menunjukan nilai t hitung sebesar 3,232 dengan signifikansi sebesar 0,002 yang lebih kecil dari tingkat signifikansi $(\alpha)=5 \%$ atau 0,05 . Hasil ini menunjukkan bahwa variable Motivasi berpengaruh positif terhadap Minat Mahasiswa Untuk Berinvestasi di Pasar Modal. Dengan demikian $\mathrm{H}_{3}$ diterima. 
Tabel 5 Hasil Uji Persamaan

\begin{tabular}{llccc}
\hline \multicolumn{1}{c}{ Variabel Dependen } & Variabel independen & $\boldsymbol{\beta}$ & $\mathbf{t}$ & Sig \\
\hline Minat Mahasiswa Untuk & Pengetahuan & 0,218 & 2,629 & 0,010 \\
Berinvestasi & Modal Minimal & $-0,157$ & $-0,778$ & 0,439 \\
& Motivasi Investasi & 0,301 & 3,232 & 0,002 \\
\hline Konstanta & 10,362 & & & \\
R & 0,567 & & & \\
R Square & 0,321 & & & \\
Adjust. R Square & 0,300 & & & \\
F Hitung & 15,287 & & & \\
Sig. F & 0,000 & & \\
N & 101 & &
\end{tabular}

Sumber: Data Primer Diolah, Peneliti (2019)

Hasil penelitian ini memberikan bukti empiris bahwa pengetahuan berpengaruh terhadap minat mahasiswa untuk berinvestasi di pasar modal. Hal ini dapat dipahami bahwa meningkatnya pengetahuan terhadap investasi yang baik akan berpengaruh terhadap peningkatan minat mahasiswa untuk berinvestasi. Pengetahuan investasi dapat diperoleh dengan mengikuti pelatihan investasi dan literatur investasi merupakan bentuk pembelajaran serta pemahaman yang harus dimiliki seseorang dalam berinvestasi sehingga pengetahuan yang baik akan meningkatkan minat mahasiswa untuk berinvestasi di pasar modal. Menurut Hurlock (1999) dalam Tandio dan Widanaputra (2016), minat seseorang dapat ditumbuhkan dengan memberikan kesempatan bagi orang tersebut untuk belajar mengenai hal yang dia inginkan. Sejalan dengan Theory of Planned Behavior, aktivitas pembelajaran akan menyebabkan suatu perubahan tingkah laku sebagai hasil dari pengalaman individu dalam berinteraksi di lingkungannya yang menyangkut kognitif, afektif dan psikomotorik (Ajzen, 1991). Pengetahuan investasi dapat diperoleh dari kajian literatur dan pelatihan pasar modal dalam seminar-seminar investasi yang diikuti dapat memberikan gambaran atau pengetahuan kepada mahasiswa tentang manfaatnya berinvestasi. Kusmawati (2011) menjelaskan bahwa pengetahuan yang memadai sangat diperlukan, hal-hal yang sangat penting untuk diketahui adalah bagaimana menilai kinerja perusahaan yang bersangkutan untuk beberapa tahun belakangan. Pengetahuan investasi sangat diperlukan untuk menghindari terjadinya kerugian saat berinvestasi di pasar modal. Hal inilah yang akan mengakibatkan ketertarikan mahasiswa untuk berinvestasi di pasar modal sehingga mempengaruhi peningkatan minat berinvestasi. Oleh karena itu perlu dilakukannya pelatihan atau seminar dan kajian literatur tentang pasar modal agar tingkat ketertarikan terhadap pasar modal semakin meningkat. para investor diharapkan memiliki pengetahuan terhadap perusahaan yang akan diinvestasi. Pemegang saham merupakan pemegang saham untuk jangka waktu relatif panjang. Pasar modal yang memiliki kualitas tinggi akan meningkatkan minat seseorang untuk berinvestasi di pasar modal. Hasil penelitian ini didukung dengan penelitiannya Sari (2018) dan Latifah (2019) yang dimana hasil penelitiannya menunjukan bahwa pengetahuan investasi berpengaruh terhadap minat berinvestasi di pasar modal syariah.

Hasil penelitian ini menunjukkan bahwa modal minimal tidak berpengaruh terhadap minat mahasiswa untuk berinvestasi di pasar modal. Hal ini menunjukkan bahwa variable modal minimal investasi tidak berpengaruh terhadap mahasiswa yang melakukan pertimbangan dalam mengambil keputusan berinvestasi. Theory of planned behavior menjelaskan bahwa pandangan tentang suatu perilaku dipengaruhi oleh keyakinan 
(behavioral beliefs) sebagai akibat dari tingkah laku yang dilakukan (Tandio dan Widanaputra, 2016). Menurut theory of planned behavior keyakinan dalam hal ini adalah modal minimal yang dimana peraturan yang diterbitkan oleh Bursa Efek Indonesia (BEI) dengan harapan dapat menarik minat untuk berinvestasi di pasar modal. Namun kenyataan lapangan yang terjadi pada penelitian ini menunjukkan hasil yang sebaliknya. Hal ini dikarenakan keputusan untuk membuka akun untuk berinvestasi di pasar modal bukan didasarkan pada ketertarikan personal akan tetapi adanya tuntutan pengaplikasian ilmu pengetahuan yang dipelajari oleh mahasiswa tentang investasi pasar modal. Sehingga modal minimal investasi bukan menjadi pertimbangan penting untuk menentukan suatu investasi. Penelitian ini didukung oleh penelitiannya Nagy dan Robert (1994) yang menyatakan bahwa saat ini investor sudah tidak lagi mempertimbangkan faktor-faktor umum sebelum berinvestasi (misalnya tren harga saham) tetapi ada faktor lain yang mempengaruhi mahasiswa untuk berinvestasi seperti professional recommendation atau para ahli bidang investasi untuk membantu investor yang belum berpengalaman dalam menentukan suatu investasi. Hasil penelitian ini sejalan dengan penelitiannya Winantiyo (2017) yang dimana hasilnya menunjukan bahwa modal minimal tidak berpengaruh terhadap minat berinvestasi di pasar modal syariah.

Hasil penelitian ini memberikan bukti empiris bahwa motivasi berpengaruh terhadap minat mahasiswa untuk berinvestasi di pasar modal. Hal ini menunjukkan bahwa semakin besar motivasi yang diperoleh maka secara otomatis mendorong minat mahasiswa untuk berinvestasi di pasar modal juga akan meningkat. Motivasi sangat berperan penting dalam menumbuhkan minat seseorang dalam berinvestasi karena motivasi adalah semangat yang mendorong seseorang untuk melakukan suatu. Latifah (2019) menjelaskan bahwa motivasi merupakan keadaan dalam pribadi seseorang yang mendorong keinginan individu untuk melakukan kegiatan-kegiatan tertentu. Pengukuran dilakukan dengan cara melihat tindakan yang diambil oleh seseorang, apakah memiliki dorongan yang kuat dalam mengambil keputusan setelah mendapatkan berbagai informasi yang mendukung suatu tindakan tersebut akan mempengaruhi minat dalam berinvestasi.

Berdasarkan Theory of Planned Behavior (TPB) menjelaskan bahwa tindakan yang diambil oleh seseorang didasari atas memenuhi kebutuhan dan hasratnya. Berbagai kebutuhan baik itu kebutuhan sosial, kebutuhan penghargaan ataupun kebutuhan aktualisasi diri dapat menjadi pemicu seseorang untuk melakukan tindakan atau keputusan di luar kehidupan sehari-hari. Salah satu contohnya adalah seseorang mengambil keputusan untuk melakukan investasi. Kebutuhan berinvestasi dilakukan oleh seseorang jika kebutuhan substansialnya sudah terpenuhi, seperti kebutuhan psikologis dan kebutuhan keamanan. Berdasarkan teori yang telah dijelaskan sebelumnya maka motivasi untuk berinvestasi di pasar modal akan timbul dari dalam diri seseorang jika berinvestasi di pasar modal dapat memenuhi kebutuhan-kebutuhan yang dibutuhkan oleh seseorang tersebut. Malik (2017) juga menjelaskan bahwa meningkatnya pertimbangan atau motivasi pembelian saham syariah adalah dengan harapan untuk mendapatkan keuntungan berinvestasi di saham syariah, keberkahan, terjaminnya pendapatan yang baik, halal, pengembangan keuangan syariah, dan menjadi pemilik perusahaan yang diinvestasikan. Hal ini berarti semakin tinggi motivasi mahasiswa berinvestasi maka minat mahasiswa untuk berinvestasi mengalami peningkatan. Hasil penelitian ini didukung oleh beberapa peneliti yakni Latifah (2019), Pajar (2017), Nisa dan Zulaika (2017) yang dimana hasil penelitiannya menunjukan bahwa motivasi berpengaruh terhadap minat berinvestasi. 


\section{SIMPULAN}

Berdasarkan analisis data pengujian hipotesis, maka dapat ditarik kesimpulan yakni pertama, pengetahuan berpengaruh terhadap minat mahasiswa untuk berinvestasi di pasar modal. Kedua, Modal minimal tidak berpengaruh terhadap minat mahasiswa untuk berinvestasi di pasar modal. Ketiga, motivasi berpengaruh terhadap minat mahasiswa untuk berinvestasi di pasar modal.

Beberapa keterbatasan dalam penelitian, yang dapat dijadikan pengembangan untuk penelitian berikutnya adalah pertama, penelitian ini hanya menggunakan mahasiswa tiga perguruan tinggi, Universitas Muhammadiyah, Universitas Khairun dan Institut Agama Islam Negeri, sehingga jumlah sasaran sampel relatif kecil. Kedua, kontribusi variabel pengetahuan, modal minimal dan motivasi terhadap minat mahasiswa berinvestasi sangat terbatas berdasarkan nilai adjust. $R$ square.

Atas dasar keterbatasan yang disebutkan di atas, maka diharapkan untuk penelitian selanjutnya dapat mengembangkan penelitian lanjutan dengan mempertimbangkan, pertama, memperluas wilayah cakupan dan menambah jumlah sampel yang diteliti sehingga diperoleh hasil penelitian dengan tingkat analisis yang lebih akurat. Kedua, Menggunakan variabel lain seperti kemajuan teknologi, pelatihan pasar modal, persepsi resiko dan persepsi return yang berkemungkinan berpengaruh terhadap minat mahasiswa untuk berinvestasi.

\section{DAFTAR PUSTAKA}

Adiguna, Richad Saputra. 2018. Kampanye 'Yuk Nabung Saham' IDX untuk Mengubah Mindset Saving Society Menjadi Investing Society. E-Journal, Vol 9 No.1.

Ajzen, I., 1991. From Intentions to Actions: A Theory of Planned Behavior dalam J. Kuhl $\mathcal{E}$ J. Beckman, Eds., Action-control: From Cognition to Behavior, Springer, Heidelberg.

Dewi, Adnantara, dan Asana. 2017. Modal Investasi Awal dan Persepsi Risiko dalam Keputusan Berinvestasi. Jurnal Ilmiah Akuntansi Vol. 2, No 2.

Efferin, Sujoko, 2006, Knowledge Economy, Knowledge Management dan Akuntansi: Prospek dan Tantangan. Jurnal Akuntansi dan Teknologi Informasi Universitas Surabaya. Volume 5 Nomor 1.

Ghozali, Imam. 2013. Aplikasi Analisis Multivariate dengan Program SPSS 23 Edisi 8. Semarang: Badan Penerbit Universitas Diponegoro.

Ghozali, Imam. 2018. Aplikasi Analisis Multivariate dengan Program IBM SPSS 25 (edisi 9) Semarang: Badan Penerbit Universitas Diponegoro.

Kusmawati. 2011. Pengaruh Motivasi Terhadap Minat Berinvestasi di Pasar Modal dengan Pemahaman Investasi dan Usia Sebagai Variabel Moderat. Jurnal Ekonomi dan Informasi Akuntansi, Vol. 1 No. 2.

Latifah, Siti. 2019. Pengaruh Pengetahuan, Modal Minimal dan Motivasi Investasi Terhadap Minat Mahasiswa Untuk Berinvestasi di Pasar Modal Syariah. Skripsi. Institut Agama Islam Negeri (IAIN) Purwokerto.

Malik, Ahmad Dahlan. 2017. Analisa Faktor-Faktor Yang Mempengaruhi Minat Masyarakat Berinvestasi di Pasar Modal Syariah Melalui Bursa Galeri Investasi UISI. Jurnal Ekonomi dan Bisnis Islam, Vol. 3, No. 1.

Nagy, R.A Robert W. 1994. Factors Influencing Individuals Investor Behavior Available from: URL: http://www.proquest.com

Nisa dan Zulaika. 2017. Pengaruh Pemahaman Investasi, Modal Minimal Investasi dan Motivasi Terhadap Minat Mahasiswa Berinvestasi di Pasar Modal. Jurnal Peta e-ISSN 2528-2581 Vol. 2 No. 2. 
Sari, Nur Siti. 2018. Pengaruh pengetahuan, keuntungan, Risiko dan Modal Minimal Terhadap Minat Mahasiswa untuk Berinvestasi di Pasar Modal Syariah. Skripsi. Institut Agama Islam Negeri Surakarta.

Pajar, Rizki Chaerul.2017. Pengaruh Motivasi Investasi dan Pengetahuan Investasi Terhadap Minat Investasi di Pasar Modal Pada Mahasiswa FE UNY. Skripsi Universitas Negeri Yogyakarta.

Raditya, Budiartha, dan Suardikha. 2014. Pengaruh modal investasi minimal di BNI sekuritas, Return dan persepsi terhadap risiko pada minat Investasi mahasiswa, dengan penghasilan sebagai Variabel moderasi. Jurnal Ekonomi dan Bisnis Vol. 3, No 7.

Sundari, Amallia. 2019. Analisis Pengaruh Modal Minimal dan Pemahaman Investasi terhadap Minat Mahasiswa Berinvestasi di Pasar Modal ditinjau dari perspektif ekonomi islam. Skripsi. Universitas Islam Negeri Raden Intan Lampung.

Tandio Thimotius, dan Widanaputra. 2016. Pengaruh Pelatihan Pasar Modal, return, Persepri Risiko, Gender, dan Kemajuan Teknologi pada Minat Investasi Mahasiswa. EJurnal Akuntansi Universitas Udayana.. No. 3. Vol.16.

Winantiyo, Aloysius Gonzaga Hastya. 2017. Pengaruh Modal Minimal Investasi, Pengetahuan Investasi dan Preferensi Risiko Terhadap Minat Berinvestasi Mahasiswa. Skripsi. Universitas Sanata Dharma. 